\title{
Microwave Applications in Food Processing: An Overview
}

\author{
Taiseer M. Abo Bakr \\ Food Science \& Technology Dept. Fac. of Agric. Alexandria Univ. El Shatby, 21545, Alexandria, Egypt. \\ Received: 29 November, 2020 \\ Revised: 16 December, 2020 \\ Accepted: 22 December, 2020
}

\begin{abstract}
In the recent years, the industrial applications of microwaves have been popular all over the world. Microwave heating has been applied in a wide range in the food processing such as cooking, blanching, drying, thawing, tempering, baking, pasteurization and sterilization. Microwave energy has many advantages than conventional heating. The present review aimed to investigate the heating of microwave and its applications in the field of food processing. Furthermore, focus on the advantages and disadvantages of microwave heating and comparison between the traditional heating methods and the heating using the microwave energy on the quality of the food products will be also highlighted. The advantages of pasteurization and sterilization of fresh juices, food fluids and other food products and their ability to exhibit inhibition for the most microorganisms at lower temperatures than the usual heating methods have been discussed. Also, using the microwave heat in drying food products suchas microwave assisted air drying,frecze drying followed by microwave, vacuum drying combined by microwave and using drying by microwave combined with the conventional drying methods were reviewed.
\end{abstract}

Keywords: Microwave, drying, cooking, blanching, baking, thawing, and pasteurization.

\section{INTRODUCTION}

Microwave was principally used for communication during the Second World War with the development of radar. Presently, the microwave heating had become so accepted all over the world. Microwave oven has become one of the common household appliances which is used for food preheating, cooking, and tempering of frozen foods. The microwave is the novel tool to attain consumer demands for food and more easier in use and saving time in its preparation. Recently, most food industries use microwave to heat, dry and sterilize many food products. Microwaves have been used successfully in many foods processing such as cooking, blanching, drying, thawing, tempering, baking, pasteurization and sterilization. Microwave heating has many benefits as compared to the conventional heating methods. These advantages are;speed of heating, saving energy, short times for start-up and shut down to reach the desired temperatures. The heat is generated throughout the food and has greater penetration depth. Also, about $80 \%$ or higher heating efficiency can be obtained. Moreover, the heating is clean,noiseless and no burned out gas is generated. It is suitable for heat- sensitive food products and multiphase fluids. Other advantages include products of good quality in terms of flavour, taste, texture, colour and nutritional contents (Ahmed \& Ramaswamy, 2007, Tewari,
2007,Chavan \& Chavan, 2010, Kalla \& Devaraju, 2017).

\section{The principle of microwave heating:}

Microwave is one of the electromagnetic radio wave. The radio wave which has a frequency band ranging from $300 \mathrm{MHz}$ to $300 \mathrm{GHz}$ is known as microwave. Two frequencies ( 915 and $2450 \mathrm{MHz}$ ) are used for microwave processing. The Microwave heating is given by the interaction between dipolar water molecules orcharged ions and electromagnetic field. When food is placed in a microwave oven, the behavior of food contents is different. The water is the principle component that absorbs heat and make food to be heated. The food which has a high level of moisture being the faster in heating. Water acts like a magnet. It has two ends opposite in charge, 2 hydrogen atoms (positive charge) and oxygen molecule (negative charge). So, water in food behaves as a magnet. Therefore, when microwave oscillate the water molecule, it will rotate due to its different poles. This because the positively charged end of water will attracts to the negative end of microwave. Meanwhile, the end of water which has a negative charge will attracts to the microwave positive end. Heat will generate as a result of molecular friction due to the rotation of dipolar molecule. Due to the strong dipole rotation of water, it is the first component which reacts with microwaves and 
produce heat. The microwaves rotate at very high speed of 2450 time / sec. So, the water molecules will rotate $2450 \mathrm{time} / \mathrm{sec}$. The water molecules will crash each other very fast to produce heat as the result of the rotation. This heat flows by convection. conduction or radiation through the food to warm it up (Fig. 1) (Kalla \& Devaraju, 2017).

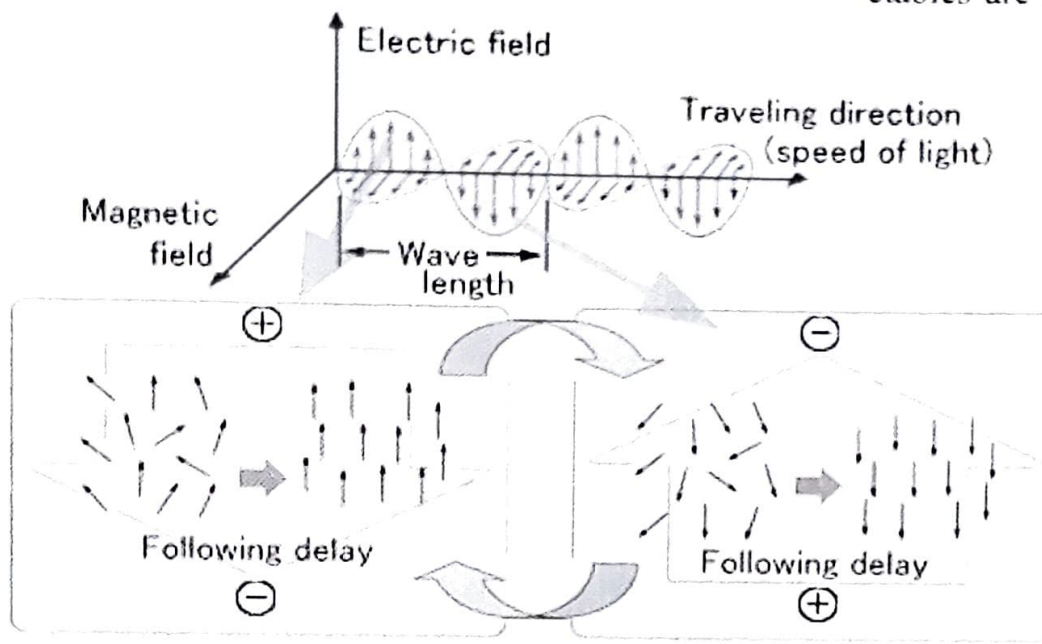

Fig. 1: Microwave heating formula and the dielectric properties of materials (Lehpamer, 2010)

Microwave travel similar to light waves. $\mathrm{Mi}$ crowave heating has some characteristics which are not found in the other conventional heating methods. These are: 1- internal heating. 2- select and rapid heating 3- clean energy and uniformity 4- rapid response and easy to control. (Figs. $2 \& 3$ ). (Oliveira \&Franca, 2002, Ahmed \& Ramaswamy 2007, Marra, et al, 2009, 2010).

\section{Microwave applications in food processing:}

\section{Cooking}

Cooking with microwave is the most familiar application of microwave at the entire world.
Microwave heating is very rapid and the food products reach the desired temperature in a short time. Cooking using microwave heating is suitable for the small amounts of foods( Sukhwant. et al., 1992).

The physical and chemical properties of vegetables are changed as a result of cooking in boiling water. Also, some reduction in dietary components were observed in cooked vegetables by microwave heating(Sukhwant, et al, 1992, Ziaur-rehman, et al, 2003, Zhang \& Hamauzu, 2004). The advantages of cooking by microwave are less loss of moisture content and minimal loss of nutrients of foods. Also, its speed. saving in energy and uniform heating through the food products. Because microwave heating penetrates inside the food matcrials, so, cooking occurred internally and rapidly through the whole volume of the food, which reduces the cooking time and energy. Moreover, because the transfer of heat is fast, flavour, colour, vitamins and most the food nutrients will be well preserved (Puligundla, et al., 2013).

Many studies on the effect of cooking using microwave heating on the food ingredients were investigated. A reduction in energy consumption was noted due to the benefits of cooking using microwave oven for raw and soaked rice comparing to the cooking in boiling water. The brown rice cooked by microwave retained higher levels of protein, fat, and ash contents as compared to steaming and conventional boiling methods (Lakshmi et al, 2007). When the legumes such as common beans and chickpeas

\section{Less loss and rapid}

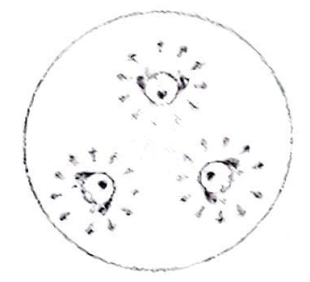

Microwave heating

\section{External heating.} takes time and many loss

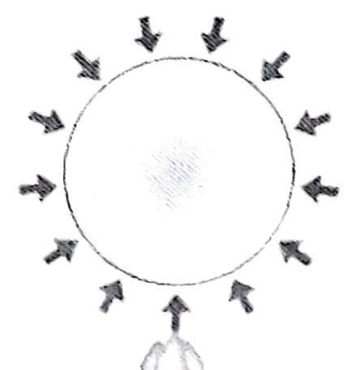

Conventional heating

Fig. 2: Microwave heats object internally (Lehpamer, 2010)

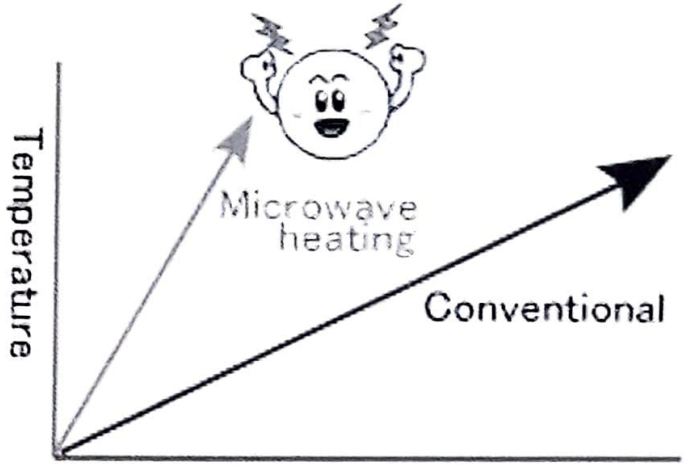

Time

Fig. 3: Microwave heating is fast (Lehpamer, 2010) 
were cooked by microwave, the time for cooking was short and they retained higher levels of the major minerals ( $\mathrm{Ca}, \mathrm{Na}, \mathrm{K}$, and $\mathrm{Mg}$ ) and the minor ones $(\mathrm{Fe}, \mathrm{Cu}$, and $\mathrm{Zn})$ comparing with the traditional cooking methods (Marconi, et al, 2000, Arab, et al, 2010).

\section{Baking}

The baking process is the first commercial application of microwave energy. At $2450 \mathrm{MHz}$, the first bread baking was reported by Ahmed\& Ramaswamy(2007). Baking is an important process in bakery industry. The dough expand during the baking process and have high volume, losses in moisture and at the final stage the moisture loss decrease as a result of the falling down of air cells in the dough due to the increased vapor pressure (Mondal, \& Datta, 2008).

Many advantages are found for using microwave in baking industry such as short time, smallspace, preserves nutrients and save energy as compared to conventional baking. Some problems are noted when baking is carried out using microwave heatingonly such as tough and quite hard texture, dry and loss of flavour and colour. Also, many studies reported that there were some problems related to the microwave bread baking such as the lack of crust formation, surface browning, less firm texture, low volume, lack of colour and rapid staling. Also, some defects were found in cakes baked by microwave such as low volumes, tough textures, lack of colour, high weight loss (Scanlon \& Zghal, 2001, Sumnu,2001).

Therefore, recently the combination of microwave with thermal energy (conventional or infiared baking)is investigated by many researchers to produce crust loaf in short time to avoid the absence of crust formation and the brown colour of loaf surface. The combination of traditional heat source with microwave energy succeeded to decrease the baking time by $50 \%$ (Sumnu, 2001, Sumnu, et al, 2005, Yolacaner, et al, 2017)

The European soft wheat with high ò-- amylase can be used with the combined process. This because the microwave heating was uniform to rise in the whole product. Therefore, the inhibition of $\dot{\alpha}$ amylase is fast enough to prevent extensive damaged starch (Tewari, 2007).

Goedeken, et al (1997) reported that the power of microwave oven should be adjusted to avoid the water loss during bread baking. Sumnu, et al,
(2005) reported that doughnut proofing by microwave heating can be completed in 4 min only comparing with 40-60 min by traditional heating methods. Also, using microwave heating in baking cookies at the final stages resulted in producing products without cracking andhave good properties.

During the conventional baking, the conductive and radiant heat heated the products from outer surface. This causes some structural changes in the ingredients of the dough such as the gelatinization of starch, denaturation of protein, increase in the volume and crust formation. While, microwave radiation interacts with water molecules, that results in the structure changes and water movement (Therdthai \& Zhou, 2003). The heating mechanism in the microwave differs from the conventional methods. In the microwave the energy absorption results in internal heating and generates internal vapor pressure (Yolacaner, et al, 2017).

Ahmad, et al. (2001) studied the radiation of high- frequency and their effect on the quality of biscuits which baked in a convection oven, followed by baking immediately in microwave oven for $30 \mathrm{sec}$. Baking by microwave reduced checking in biscuits to $5 \%$ as compared with $61 \%$ in conventional baking and less affected to checking when exposure to high humidity.

Microwave baking do not have the ability to form browning as the conventional methods in baked products (Chavan\&Chavan, 2010). Durairaj, et al.(2009) reported that ceramic layer is useful in decrease the thermal runaway and enhance the power absorption in food samples by the ceramic layers in the microwave oven.

Some studiesfound that using microwave ovens provide with infrared heating will enhance the quality of the baked products (Datta \& Ni, 2002, Sevimli, et al., 2005). Today the most important use of microwave heating is in the final stages of the baking industry, when the conventional processes lead to longer baking times (Kumar, 2015).

\section{Drying:}

The food preservation by drying process is used for many products, especially fruits and vegetables to extend self-life (Doymaz, 2006). So, new methods are used to shorten the drying time and decrease of the consumption of energy. The benefits of microwave heating are its penetration depth and the uniform heating. Microwave drying is used 
to shorten drying time to an extent of about 9095\%and saving energy consumption as compared with the conventional air drying. Also. only 20 $35 \%$ of the floor is needed for microwave system (Maskan, 2000. Ahmed \&Ramaswamy. 2007).

Microwave drying of food is used in the final stage (falling period) of drying food products because the migration of water from the center of the products is decreased. The mechanism of drying with microwave is different from the traditional hot air drying method. Drying food using microwave heating, the heat is generated through the product causing higher heat transfer. Also, the temperature rises more faster than in conventional drying (Gowen, et al. 2008, Chandrasekaran. et al, 2013.Gaukel, et al, 2017)

The microwave drying cause too much high temperature at the edges of the food products during the final stages of drying which results in production off flavours. So, the use of microwave drying in food processing at a commercially industry was for drying products in the final stage of drying. In the food industry it could be used two - stage drying process involving conventional drying at the initial stage using forced air followed by microwave drying (Ahmed\& Ramaswamy, 2007). It was found that the drying time of banana slices reduced by $64 \%$ when hot air drying combined with microwave (at $350 \mathrm{~W}$ ), as compared to the air drying method (at $60^{\circ} \mathrm{C}$ ). The banana samples took place a longest time in the falling rate period by air drying. Meanwhile, the samples were lighter in colour and, the product had excellent taste, no shrinkage and good flavour (Maskan, 2000, Chandrasekaran et. al. 2013, Kumar. 2015).

Bouraoui, et al,( 2007) studied three different methods for drying potato slices ( microwave heating, convective drying and combined microwave and convective drying ). The results showed that the drying by microwave heating producing dried potato slices of better quality and reducing drying time. Microwave drying at low power have a good effect on the quality of dried apple slices. The coating material affects the textural quality of the slices such as texture strength(Askari, et al. 2006).

Pasta is made from semolina by steps include. hydration, mixing. kneading and extruding to obtain the different shapes then drying. The drying step is the difficult and critical to obtain pasta of high quality. It is difficult because the moisture mi- grates slowly to the surface when hot air is used. Using microwave heating will provide a positive moisture flow to the surface. In many countrics. pasta products and noodles are dried successfully by microwave at $915 \mathrm{MHz}$ at a commercial scalo (Goksu et al.. 2005)

Szadzinska. of ol.(2019) investigated the microstructural alicration, and rehydration propertics of the dried rasplesty using dring with the application of microwaves (MW) and uitrasound (US) and convective drying (CV) as a reference method. The results showed significantly shorter drying time by $54.4 \%$ for $\mathrm{CV}$ followed by US and $69 \%$ for $\mathrm{CV}$ combined by MW comparing to CV. Also, and a lower energy consumption resulting in energy saving of 14 to $23 \%$ for $\mathrm{CV}$ followed by US and $54 \%$ for $\mathrm{CV}$ combined with MW. as compared to CV

Ultrasound and microwaves were applied in drying red beetroot using convective drying continuously (hybrid processes) or periodically (hybrid intermittent processes). The drying processes were evaluated in terms of drying time, drying rate. and energy consumption. Furthermore, the total colour change, retention of natural dye (betanin). water activity, texture, and microstructure of dry product were examined. It was found that hybrid intermittent drying reduces the total drying time and cnergy consumption, enhances both the drying rate and product quality, it was demonstrated that the hybrid intermittent drying can serve as an alternative to conventional hot air drying that could produce a more porous, nice colour, and crispy vegetable products (Szadzińska, et. al.,2020).

Microwave assisted vacuum drying. Zhang et al. (2006) reported that the thermal efficiency has been improved when microwave was combined with vacuum drying. Microwave vacuum drying was used for various cereal grains, concentration of citrus juice and for production of grape puffs. Many studies reported that microwave applications wers used for drying fruits and vegetables (Marra, et al. 2010)

Zielinska et. al. (2019) investigated hot air convective drying (HACD) and microwase vacuum drying (MWVD) on the drying kinetics and quality of whole cranberries in terms of texture. It was found that drying times were shorter for the samples dried by MWVD as compared to the samples dried by HACD. Moreover, cranberries processed by MWVD were significantly had greater hardness, gumminess, and chewiness as compared 
to HACD samples. Also, the texture was hard and crispy and resistance to stress associated with manufacturing, packaging and storage. Meanwhile, HACD produced brittle fruits that were difficult to store and transport and were not fully suitable for direct consumption. Furthermore, when freezing was followed by MWVD the overall appearance of cranberries was improved.

Freeze drying is the method used to preserve the sensitive food products in good quality. It needs a long processing period and consumed great amount of energy. So, microwave can help the freeze drying to produce food products of high quality similar to that of vacuum freeze drying and can shorten the drying period effectively. The drying rate in microwave freeze drying of cabbage was more effective than that of vacuum freeze drying (Kalla\&Devavju, 2017)

The falling rate period in the fluidized bed dryers is long drying time. However, using microwave heating combined with fluidized bed dryers can overcome this disadvantage (Chen, 2001, Puligundlaet al, 2013, Kumar, 2015)

Using vacuum drying can produce a more porous dehydrated products compared by air dried products. Drying by hot air had many disadvantages such as lengthy time and low energy efficiency. This is due to the rapid reduction of surface moisture transfer. This resulted in reducing the quality of food. So, to overcome these disadvantages microwave was combined with hot air drying (Masken, 2001, Sharma \& Prasad, 2001).

Botha et al, (2012) found that when using osmotic dehydration for drying pre- heated samples of pineapple, they were dried quickly by using microwave at different power conditions and had a good quality.

Carrot slices dried with microwave vacuum drying contained high content of $\dot{\alpha}$ - carotene and vitamin $C$, also had soft texture and good colour than that of air drying. Also, carrot slices dried at $400 \mathrm{~W}$ power by microwave retained about $88 \%$ of its $\beta$ - carotene (Mayer-Miebach, et al, 2005). The kinetics and drying properties of potato slices were studied using different microwave powers and vacuum pressure by Song, et al, (2009).

\section{Blanching}

In the blanching process the food products are exposure to boiling water, steam or boiling solutions containing salts or acids to inactivate the enzymes which catalyze the oxidation of food products and cause undesirable changes in texture, colour and flavour of the food products. This process is an essential step in food processing such as canning, drying and freezing. Also, blanching serves to decrease the microbial load of the food products and eliminate dissolved oxygen from the food (Maskan, 2000, Ahmed \& Ramaswamy, 2007).

In general, hot water or steam is commonly used in the blanching step in the food industry. The traditional blanching method is associated with a reduction in weight and leaching some nutritive components such as sugars, water soluble vitamins and minerals (Maskan, 2000, Ramesh, et al, 2002).

To keep the nutritional quality of food products, microwave blanching can be used to reduce the leaching of nutrients in water, since it requires little amount of water for efficient heat transfer in food products (Ponne, et al, 1994, Ramesh, et al, 2002, Lin \& Brewer, 2005, Puligundla, et al, 2013).

The advantages of blanching using microwave compared with traditional methods include saving consumed energy, speed of operation, no additional water requirement, precise process and faster times for start - up and shut down. The combination of microwave heating with initial hot water or steam could provide an excellent economic benefit. Steam or low cost hot water were used first to raise the temperature, then microwave heating does the more difficult and the high cost of internally blanching stage of food products. Furthermore, blanching by microwave will finish the blanching of the centers quickly regardless to the thick or non-uniform sections (Shaheen, et al, 2012).

Also, when using microwave to inactivate enzymes (peroxidase, catalase, polyphenol oxidase and pectinase), a reduction in time and energy were achieved as compared with the traditional methods. Furthermore, the bioactive compounds were enhanced and avoid the leaching effect of water blanching for the phytochemicals due to the short time required by microwave blanching. The food materials blanched with microwave include vegetables, fruits, leaves, tubers, and mushrooms (Dorantes- -Alvares et al, 2017, Kalla \& Devaraju, 2017).

Using microwave heating in blanching process was preferred than using hot water or steam in blanching step because leafy vegetables can retain its maximum green colour, vitamin C (ascorbic acid) 
and chlorophyll contents. Also, it is more effective in retaining water-soluble vitamins and other nutrients as compared to the traditional blanching methods. Microwave heating were carried out for blanching many vegetables like, carrots, mushroom, sweet potato, peas, pepper, beet and green beans. Furthermore, maximum retention of red pigments and total antioxidant activity were found in all the treatments (Severini, et al,2016, Wang et al, 2017).

However, using the microwave heating can lead to some problems such as non-uniform for heating and distribution of the energy which causes hot and cold points in the product (Chandrasekaran. 2013, Xiao, et al , 2017).

\section{Pasteurization and sterilization:}

Pasteurization is the process that uses relatively mild heat treatment on foods. The main goals of pasteurization are to destroy pathogenic microorganisms and inactivate some enzymes in foods. It is usual method used to extend the storage period and shelf-life of food products to make food safe for consumption like milk and fruit juices, where minimum process is necessary to minimize healthassociated. The absorbed energy from microwave causes a rise in the temperature of the food to be high enough to destroy the pathogenic microorganisms such as bacteria by thermal treatment and to inactivate the undesirable enzymes in foods (Nott \& Hall, 1999, Tewari, 2007, Guo, et al,2017).

Pasteurization can be achieved by many methods such as ohmic heating, non-thermal technologies (UV light, high hydrostatic pressure, high intensity ultrasound, pulsed electric field and ionizing radiation)( Pereira\& Vincente, 2010).

Microwave destroys the microorganisms at sublethal temperatures can be explained by different theories:1-The theory of selective different heating: the microorganisms are selectively heated to higher temperature than the fluid surrounding it and killed very quickly. 2- Electroporation theory: the cell membrane had pores as a result of electrical potential, which causes the drainage of cellular materials. 3-Cell membrane method: the voltage applied causes rupture in the cell membrane. 4Magnetic ficld theory: the coupling electromagnetic energy causes disrupted of some components of the cell like protein of the DNA. Also, the polar and / or charged moieties of proteins ( $\mathrm{COO}$, and $\mathrm{NH}_{4}$ ) are affected by the electrical component of the microwaves and the disruption of non-covalent bonds by microwaves cause of speedy microorganisms' death (Kozempel, et al, 1998, Koulchma. et al.2001).

Salazer-Gonzalez, et al, (2012) reviewed the using of microwave pasteurization of many liquid foods such as different fruit juices, milk, coconut milk and sweet potato puree and they reported that desired lethality could be obtained. Microwave pasteurization of ready-to-eat meals has also been found to be a commercial success in European countries although US industries are still reluctant to use this technology. Moreover, microwave pasteurization of packaged products is possible for different packaging materials (plastic, paper, and glass).

It was found that pastcurization of eggs shell by microwave can be achieved without losing the shell integrity. Also, the inhibition of Salmonella in the yolk of eggs can be obtained by microwave pasteurization. About 22\% reduction of microbes was attained for microwave heating for $15 \mathrm{sec}$. Whereas, about $36 \%$ reduction was obtained using moist heat treatment for $15 \mathrm{~min}$ (Dev, et al., 2008,Shenga, et al., 2010).

Sterilization is a more severe thermal treatment of foods. The process is designed to achieve commercial sterility of the food products, giving it longterm shelf foods. The traditional heat sterilization is mainly carried out by heating and is characterized by slow heat transfer and long sterilization time, which seriously affects the quality of food products. Therefore, microwave heating has the advantage of overcoming the limitation imposed by slow thermal diffusion of conventional heating. Some researchers have claimed non-thermal or enhanced thermal effects, to be associated with microwave heating on the destruction of microorganisms and inactivation of enzymes (Ahmed. \& Ramaswamy, 2007, Kalla, \& Devaraju, 2017). To preserve fluid foods, the process of high - temperature short- time (HTST) has been used to avoid the thermal degradation in food quality. But for solid foods, the HTST is not suitable due to the slow penetration of heat and overheating of the solid surface during the time of heating. Meanwhile, heating by microwave will overcome the slow heat penetration of traditional heating methods. The heat produced by microwave will shorten the time of heating as compared to the commercial sterilization (Ahmed\& Ramaswamy, 2007, Vadivambal \& Jayas, 2010). 
Sterilization of food products packed in different materials can be achieved by using new techniques like microwave irradiation. Ultra Violet light (UV). cold plasma and ozone. Some packaging materials may migrate into food materials. Benzene may be produce as a result of the high temperature of microwave beating due to the leaking of some polymers or adhesive components of packaging materials. So. paper. glass and ceramics wete preferred for using in microwave packaging (Guilard. et al. 2010. Chandrasekaran, 2013). When macaroni packed in pouches with cheese were preserved by sterilization using heat of microwave at 950 $\mathrm{MHz}$, no changes in the taste. texture or flavour of the products were observed (Estcve, et al., 1998). According to U.S. Food and Drug Administration (FDA) (2019) the non-1hermal inactivation effect of microwave process on the destruction of microorganisms and inactivation of enzymes is not sufficient to use in sterilization of all types of food. It is recommended to include only thermal effects in the models. The sterilization of potatoes and fish fillet using in pouches was approved recently by the FDA. The process was carried out by dipping the food package in boiling or hot water and usingthe heat of microwave at a frequency of $950 \mathrm{MHz}$. The food pathogens and spoilage bacteria will be eliminated in 5 to $8 \mathrm{~min}$ and the products were safe and have good quality (Brody, 2012).

Several studies demonstrated that the application of microwaves in the sterilization of foods is limited due to the uneven heating of the product during sterilization. Also, the temperature of the product at some locations does not reach the real temperature distribution during microwave heating. Other researchers reported that replacement of the conventional heating by microwave energy as only heating source is impossible without understanding the real heating and inactivation mechanisms, temperature distribution in all layers of foods and other critical factors. To distinguish between thermal and no thermal effects on destroying microorganisms, most studies used the experiments under identical heating conditions to evaluate the inactivation effects of conventional and microwave heating. The major drawback in the microwave sterilization is the lack of availability of actual temperature protiles. Measurement of temperatures at some locations does not guarantec the real temperature distribution in the food product during heating by microwave (Nguyen, el al 2013. Peng, er al, 2017 Michalak. et al, 2020).

\section{Thawing and tempering:}

Thawing of frezen food products is the reversal process of freezing. Thawing is the process used for change the frozen products from frozen state to reach temperature of $0^{\circ} \mathrm{C}$ and be free from ice (unfrozen state) or defrosting. Before cooking the frozen foods should be thawed. to be sure that the food during cooking is sufficiently heated to destroy the spoliage microorganisms. When conventional thawing methods are used. it will take a long time. the outer surface of food product will be the first area which rise in the temperature and results in bacteriological and chemical deterioration. Thawing using hot an or water will subject the outer surfaces of frozen meat blocks to high temperatures for a long time. Microwave heating is usually used for thawing food products becausc its heat is generated from the center to the surface and the process will be more faster than the conventional thawing (Shahecn, ef al.. 2012. Kalla \& Devaraju. 2017).

The heating of microwave is usually used for thawing frozen bread. It was reported that some bakery products thawed or heated by microwave have low quality, due to presence of some bad properties such as lack of browning. low volume. navour changes, tough, difficult to chew crumb and bread staling after short time of heating (Sumnu, 2001).

The disadvantagesof using microwave in thawing process are the phenomenon of runaway heating due to the unbalance in heating and the higher amount of power absorption in liquid parts of the materials. So. it is important to adjust the heat produced by the microwave ovens. At commercial practice few quantities of frozen products such as frozen meat, vegetables, fish. fruits and juice concentrates are thawed by microwave heating (Kalla \& Devaraju, 2017).

The tempering process is usually carried out at temperature below freezing point (generally bellow- $18^{\circ} \mathrm{C}$ ) and ranged between -5 to $-2 \mathrm{C}$, where the water in the food product is turned to ice but not all the quantity of water changed to ice. At this temperature the product will be strict but not hard. Many studies reported that complete thawing the frozen foods completely by microwave is not practical. Therefore, tempering by microwave showed great benefits and can be used instead or alternative to thawing. At the tempering temperature, the texture and the product firmness are intact and permits 
further proccasing withous caveing ham. Tentwer. ingt is more commorly used in the technous for the proviuct that are ahtioquently requrred aze reducknon, and 14 waich quan the thaw ing Tempering alu roduces problems such as drop in the frozen products and hactertal gromith that are ascocuated with the thawing Furhermore. it can handle large amounts of frozen product at small cost has a high yeld, and is accomplished in small spaces with no bacterial growth compared to tradumomal tempering icchniques evithes with water of air ic hizohast al. $2(1)$ 7)

In many times it is not important to complete the thawng to save enctgy, the ume will be shomer and obtann products of good qually. The frozen meat is usually found in large pieces. So. in order to cut and slice the frozen meat. it should he icmpered firsly. Therefore. the pieces will be compered from the bard state lo a temperature to be caster for cutting without damage the product. The compcrature used for tempering will be according whe thapes of picces. the method used for cutting. slemg and the composition of food product such as mossure fass, and proteins. Traditional tempering methods usually use hot air and water: in this case the meat surfaces from outside will subject to high temperatures for long periods until the licat reaches the center of the product. Tempering microwave has been carried oul for forzen foods such as fish. meat and poultry cither in different methods such as batch or comfinuous systems

The adrantages of microware fempering are handing lange quantitics of frozen products. low cost. oceup tempering of bulky products due to its oceper penctration in the product as compared to the frequency of $(2450 \mathrm{MHz})$ (high band) monowand Ahmede Ramaswamy 2007 , Shahencs al. 2012. Ralla \& Deraraju, 20171

\section{The main advantages and disad antages of microwave heating:}

In concluson, matrowate heang presents whe ad attages and disad antages in companson to the convemional techmqua a reponed by wne recanchen (Salazar-Gonzaler, ol al, 2012, ChanAracharan, of al, 201: Kumat, Z0!5, Kalla a

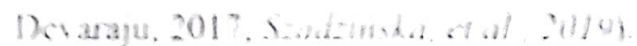

\section{The advantages:}

taster heating: the merouate hea generates

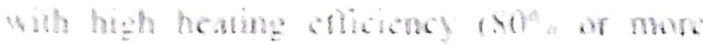
whicial

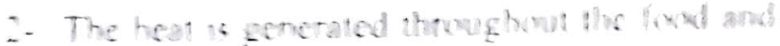
has greater penettation depth

3. Shomer prowesing thme 11 use atwout a quatlet of the trme used in the cunventomal hoatung and requites shom mones for start-up and shon dran to reach the docenol iomporatures

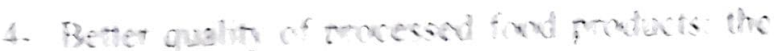
target nemperature reached quich din to the high hoating ratc. thus roducing the hambul cf. fects of thermal heating on the fond and it is more effoctove in retainung the mutrients componeris of the fond products

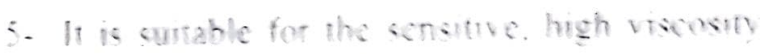
and muluphase flunds.

6. It is safe to handle the packot foods after me crowave pasteurnation

7. Ease of operaton. small space requement and low cnergy consumption (high cffictency). reduction of nose levels, and low mamtenance $\cos 4$

8. Emironmentally it is clean cuergy, and does not produce toxics gases or any pollutants wastes.

\section{The disadvantages:}

1. The mictowave ovens usually use clectrienty. which is high in costs

2. It is much expenswe to build long towers

3. To obtain high quality food products, if nects qualified engineers who have experienes to de velop this novel technology for uving at indus. irial scale

+- Microwave heating is not surtable for forcus baking because bread staling may occur quick. er as compared with the comentiocal bakst methods

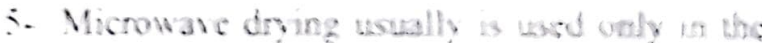
falling poriod of dry ing mant produrts

6. Applying morowave beating us dry zag of some food products may cakse tow much heating at the odges and comer of the products rexulted in ort-1lavours and unacespeable was:

7. In order w us mocrow at bealing in the dryang of food producth, if should combins the dryong

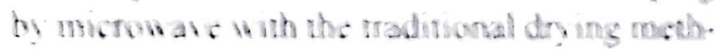
als 10 achere products of high qualury

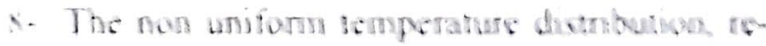
suling in bes and cold s pots maunly un solid and

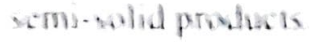




\section{REFERENCES}

Ahmed, J. \& Ramaswamy, H. S. 2007. Microwave pasteurization and sterilization of foods. In: Handbook of Food Preservation, 2nd Ed. (Rahman, S. M. (Ed), CRC Press, Taylor and Francis Group. New York. pp: 691-709.

Alımed. S. S., Morgan. M. T. \& Okos, M. R. 2001. Effects of microwave on the drying, checking and mechanical strength of backed biscuits. Journal of Food Engineering. 50: 63-75.

Arab, E. A.A., Helm, I. M. F. \& Bareh, G. F. 2010. Nutritional evaluation and functional properties of chickpea (Cicerarietinum L.) flour and the improvement of spaghetti produced from it. Journal of American Society, 66: 1055 1072.

Askari, G. R., Emmam-Djomeh, Z., \& Mousavi, S.M. 2006. Effect of combined coating and microwave assisted hot- air on the texture, microstructure and rehydration characteristics of apple slices. Food Science and Technology, 12: 39-46.

Botha, G. E., Oliveira, J. C. \& Ahrne, L. 2012. Microwave assisted air drying of osmotically treated pincapple with variable power programmers. Journal of Food Engineering, 108: $304-312$.

Bouraoui, M., Richard, P. \& Durance, T. 2007. Microwave and convective drying of potato slices. Journal of Food Process Engineering, 17: 353-363.

Brody, A. I., 2012. The coming wave of microwave sterilization and pasteurization. Food Technology Magazine, 66: 78- 80.

Chandrasekaran, S., Ramanathan, S., \& Basak, T. 2013. Microwave Food Processing - A review. Food Research International, 52: 243261.

Chavan, R.S.\& Chavan, S.R., 2010. Microwave baking in food industry. A review. International Journal of Dairy Science, 5: 113-127.

Chen, G., Wang, W. \& Mujumdar, S. 2001. Theroretical study of microwave heating patterns on batch fluidized bed drying of porous material. Chemical Engineering Science, 56: 6823-6835.

Chizoba, E. F. G., Sun, D. W., Han, Z., \& Cheng, J. H. 2017. Microwave-assisted food processing technologies for enhancing product qual- ity and process efficiency: A revicw of recent developments. Trends in Food Science and Technology, 67: 58-69.

Datta. A. K., \& Ni, H. 2002. Infrared and hot -air assisted microwave heating of foods for control of surface moisture. Journal of Food Engineering, 51: 355-364.

Dev, S. R. S., Raghavan, G. S. V. \& Gariepy, Y. 2008. Diclectric propertics of egg components and microwave heating for in- shell pasteurization eggs. Journal of Food Engineering, 86: 207- 214.

Dorantes-Alvares, L.. Ortiz-Moreno, A., GuzmanGeronimo, R., \& Parada- Dorantes. 2017. Microwave- assisted blanching. In: The Microwave Processing of Foods. (Schubert, H. \&Regier, M. (Eds). Cambridge CRC press, pp: 179-199.

Doymaz, L. 2006. Drying kinetics of black grapes treated with different solutions. Journal of Food Engineering, 76: 212-217.

Durairaj, S., Chaudhary, A. \& Basak, T., 2009. Efficient microwave heating of discrete food samples layered with ceramic composites. Journal of Food Engineering, 95: 62-75.

Esteve, M. J., Frigola, A., Martorwll, L., \& Rodrigo, C. 1998. Kinetics of ascorbic acid degradation in green asparagus during heat processing. Journal of Food Protection, 61: 1518- 1521.

Food and Drug Administration. 2019. Kinetics of microbial inactivation for alternative food processing technologies - microwave and radio frequency processing. Available online: http://www.fda.gov/Food/ScienceResearch/ ResearchAreas/SafePracticesforFoodProcesses/ucm 100250.htm (accessed on 18 April 2019).

Gaukel, V., Siebert, T., \& Erle, U. 2017. Microwaveassisted drying. In: The Microwave Processing of Foods (Schubert,H.\&Regier,M.(Eds). Cambridge CRC press, pp: 152-178.

Goedeken, D. L., Tong, C. H. \& Virtanen, A.J. 1997. Dielectric properties of a pregelatinized bread system at $2450 \mathrm{MHz}$ as a function of temperature, moisture, salt and specific volume. Journal of Food Science, 62: 145-149.

Goksu, S.O.. Sumnu, G. \&Esin, A. 2005. Effect of 
microwave on fluidized bed drying of macaroni beads. Journal of Food Engineering.66: 463-468.

Gowen, A. A.. Abu- Ghannam. N.. Frias, J., \& Oliveria. J. 2008. Modeling dehydration and rehydration of cooked soybeans subjected to combined microwave-hot air drying. Innovative Food Science and Emerging Technologies, 9: 129-137.

Guilard, V. Mauricio- Lglesias, M., \& Gontard, N. 2010. Effect of novel food processing methods on packaging: structure, composition and migration properties. Critical Reviews in Food Science and Nutrition, 50: 969-988.

Guo, Q., Da-Wen, S., Jun-Hu, C., \& Zhong, H., 2017. Microwave processing techniques and their recent applications in the food industry. Trends in Food Science and Technology, 67:236-247.

Kalla A., M.\&Devaraju, R. 2017. Microwave energy and its application in food industry: A review, Asian journal of Dairy and Food Research, 36: 37-44.

Koulchma, T., Le Bail, A.\& Ramaswamy, H.S. 2001.Comparative experimental evaluation of microbial destruction in continuous- flow microwave and conventional heating system. Canadian Biosystems Engineering, 43: 3.13.8.

Kozempel, M. F., Annous, B.A., Cook, R. D., Scullen, O.J., \& Whiting, R. C. 1998. Inactivation of microorganisms with microwave at reduced temperatures. Journal of Food Protection, 61: 582-585.

Kumar, Y. 2015. Application of microwave in food drying. lnternational Journal of Engineering Studies and Technical Approach, 01: 9-23.

Lakshmi, S.. Chakkaravarthi, A., Subramanian, R.. \& Singh, V. 2007. Energy consumption in microwave cooking of rice and its comparison with other domestic applications. Journal of Food Engineering, 78: 715-722.

Lehpamer, H. 2010. Basics of microwave. In: Microwave Transmission Networks: Planning. Design, and Deployment. www. microdenshi. co.jp/en/microwave/index.html.

Lin, S. \& Brewer, M. S. 2005. Effectof blanching method on the quality characteristics of frozen peas. Journal of Food Quality, 28: 350360 .
Marconi. E.. Ruggeri. S.. Cappelloni, M.. Leonardi, D. \&Carnovale. E. 2000. Physicochemical. nutritional and micro structural characteristics of chickpeas (Cicer arictinum L.) and common beans (Phaseolus vulgaris L.) following microwave cooking. Joumal of Agriculture and Food Chemistry. 48 : 5988- 5994

Marra. F.. De Bonis. M. V., Ruocco,\& ConvectionG. 2010. Combined microwaves and convection heating: A conjugate approach. Journal of Food Engineering. 97: 31-39.

Marta, F.. Zang, L.,\& Lying, J. G. 2009. Radio frequency treatment of foods: review of recent advances. Journal of Food Engineering. 43: 243-250

Maskan, M. 2000. Microwave/air and microwave finish drying of banana. Joumal of Food Engineering, 44: 71-78.

Maskan, M. 2001. Drying, shrinkageand rehydration characteristics of kiwifruits during hot air and microwave drying. Journal of Food Engineering. 48: 177-182.

Maycr-Micbach, E., Belssnilian, D., Regicr. M., \& Schuchmann, H.P., 2005. Thermal processing of carrots: lycopene stability and isomerisation with regard to antioxidant potential Food Research International, 38: 1103-1108.

Michalak, J.Y., Czarnowska-Kujawska, M., Klepacka, J. \& Gujjka, E. 2020. Effect of microwave heating on the acrylamide : review. Molcules. 25 : 4140.

Mondal, A. \& Datta, A.K. 2008. Bread making- a review. Journal of Food Engineering, 86 465-474.

Nguyen, L.T., Choi, W., Lee, S.H.\& Jun, S. 2013 Exploring the heating patterns of multiphase foods in a continuous flow, simultaneous microwave and ohmic combination heater. Journal of Food Engineering, 116:65-71.

Nott, K. P. \& Hall, L. D. 1999. Advances in temperature validation of foods. Trends in Food Science and Technology, 10: 366- 374.

Oliveira,M.E. C. \& Franca, A.S. 2002. Microwave heating of foodstuffs. Journal of Food Engineering, 53: 347-359.

Peng, J., Tang, J., Donglei, L., Frank, L. B., Zhongwei, T. B., Feng. L. B. C., \& Wenjia, Z. 2017. Microwave pasteurization ofpre-packaged carrots. Journal of Food Engineering, 202: $56-64$. 
Pereira, R.N. \& Vincente, A.A., 2010. Environmental impact of novel thermal and non- thermal technologies in food processing. Food Research International. 43: 1936- 1943.

Ponne, C.T., Baysal, T., \&Yuksel, D. 1994. Blanching leafy vegetables with electromagnetic encrgy, Journal of Food Science, 59: 1037. 1041.

Puligundla, P., Abdulla, A.S., Choi, W., Jun. S. Sang-Eun, O.H., \& ko, S., 2013. Potentials of microwave heating technology for select food processing applications - a brief overview and update. Journal of Food Process Teclinology, 4: 1-9.

Ramesh, M.N., Wolf, W., Tevini, D., \&Bognar, A. 2002. Microwave blanching of vegetables. Journal of Food Science, 67: 390-398.

Salazer- Gonzaler, C., San Martin- Gonzaler, M.F., Loppez-Malo,A., \& Sosa- Morales, M.E. 2012. Recent studies related to microwave processing of fluid foods. Food Bioprocess and Technology, 5: 41- 46.

Scanlon, M.G. \& Zghal, M.C. 2001. Bread properties and crumb structure. Food Research International, 34: 841-864.

Severini, C., Giuliani, R., De Filippis, A., Derossil, A., \& De Pilli, T., 2016. Influence of different blanching methods on color, ascorbic acid and phenolics content of broccoli. Journal of Food Science and Technology, 53:501-510.

Sevimli, K.M., Sumnu, G.,\& Sahin, S. 2005. Optimization of halogen lamp - microwave baking of cakes: a response surface methodology study. European Food Research Technology, 221: 61-68.

Shahen, S. M., El- Massry. F.K., El-Ghorab, H. A., \& Anjum, M. F. 2012. Microwave application in thermal food processing. In: The Development and Application of Microwave Heating. Wenbin Cao (Ed), pp: 1-16. INTECH, Science technology and medicine Access Publisher.

Sharma, G.P. \& Prasad, S. 2001. Drying of garlic (Allium sativum) cloves by microwave- hot air combination. Journal Food Engineering, 50: 99-105.

Shenga, E., Singh, R.P., \& Yadav, A. S. 2010. Effect of pasteurization of shell egg on its quality characteristics under ambient storage.
Journal of Food Science and Technology Mysore. 47: 420- 425.

Song, X., Zhang, M., Mujumdar, A. S. \& Fan, L. 2009. Drying characteristics and kinetics of vacuum microwave - dried potato slices. Drying Technology, 27: $969-974$.

Sukhwant. M. K.. Harvindr, K.. \& Tejinder, G. 1992. Effect of cooking on fibre content of vegetables. Journal of Food Science and Technology. 29: 185- 186.

Sumnu. G., 2001. A review on microwave baking of food. International Journal of Food Science and Technology, 36: 117-127.

Sumnu, G., Sahin, S.,\& Sevimli, M., 2005. Microwave, infrared and infrared- microwave combination baking of cakes. Journal of Food Engincering, 71:150-155.

Scverini, C., Giuliani, R., De Filippis, A., Derossil, A., \& De Pilli, T., 2016. Influence of different blanching methods on color, ascorbic acid and phenolics content of broccoli. Journal of Food Science and Technology, 53:501-510.

Szadzińska,,J., Lechtanska,I., Pashminehazar, R. Kharaghani, A. \&Tsotsas, E. 2019. Microwave- and ultrasound-assisted convective drying of raspberries: Drying kinetics and microstructural changes. Drying Technology, $37: 1-12$.

Szadzińska,,J., Mierzwa, D., Pawłowski, A., Musielak, G., Pashminehazar, R. \&Kharaghani, A. 2020. Ultrasound- and microwave-assisted intermittent drying of red beetroot. Drying Technology, 38: 93-107.

Tewari, G. 2007. Microwave and radio- frequency heating. In: Advances in Thermal and Non- Thermal Food Preservation. Tewari, G.\&Juneja, V. K. (Eds). Blackwell Publishing. pp: $91-98$.

Therdthai, N. \&Zhou, W.B. 2003. Recent advances in the studies of bread baking process and their impact on the bread baking technology. Food Science and Technology Research, 9: 219- 226.

Vadivambal, R.\& Jayas, D.S. 2010. Non-uniform Temperature Distribution During Microwave Heating of Food Materials: A Review. Food Bioprocess Technology, 3; 161-171.

Wang, J., Xu-Hai, Y. A. S., Mujumdar, D. W., JinHong, Z., Xiao-Ming, F.. Qian, Z., Long, X., 
Zhen-Jiang, G., \& Hong-Wei, X. 2017. Effects of various blanching methods on weight loss, enzymes inactivation, phytochemical contents, antioxidant capacity, ultrastructure and drying kinetics of red bell pepper ( $\mathrm{Cap}$ sicum annumm L.). LWT - Food Science and Technology, 77: 337-347.

Xiao, H.-W., Pan, Z., Deng, L.Z., El-Mashad, H., Yang, X.H., Mujumdar, A.S., Gao, Z..J.\& Zhang, Q. 2017. Recent developments and trends in thermal blanching-A comprehensive review. Information Processing in Agriculture. 4:101-127.

Yolacaner, E.T., Summnu, S., \& Sahin, S. 2017. Microwave assisted baking, In: The Microwave Processing of Foods.(Schubert, H. \& Regier, M (Eds).Cambridge CRC press. pp 117-141.
Zhang, D. \& Hamauzu, Y. 2004. Phenolics, ascorbic acid, carotenoids and antioxidant activity of broccoli and their changes during couventional and microwave cooking. Food Chemistry, 88: 503-509.

Zhang, M., Tang, I., Mujumdar, A. S. \& Wang, S. 2006. Trends in microwave-related drying of fruits and vegetables. Trends in Food Science and Technology, 17: 524-534.

Zia-ur-Rehman, Z., Islam, M.,\& Shah, W. H. 2003. Effect of microwave and conventional cooking on insoluble dietary components of vegetables. Food Chemistry, 80: 237-240.

Zielinska, M., Markowski, M.\&Zielinska, D. 2019. The effect of freezing on the hot air and microwave vacuum drying kinetics and texture of whole cranberries. Drying Technology, 37: $1714-1730$

\section{تطبيقات استخلام الهيكروويف فى مجال التصنيع الغذائى : نظرة شاملة}

$$
\begin{aligned}
& \text { تيسير محمود أبوبكر }
\end{aligned}
$$

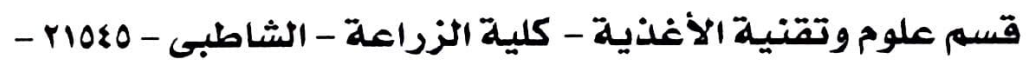

$$
\begin{aligned}
& \text { جامعة الأكندرية - الأسكندرية - مصر } \\
& \text { انتشر فى السنوات الأخيرة استخدام تطبيقات الميكروويف العديدة في جميع أنحاء العالم. تطبيقات }
\end{aligned}
$$

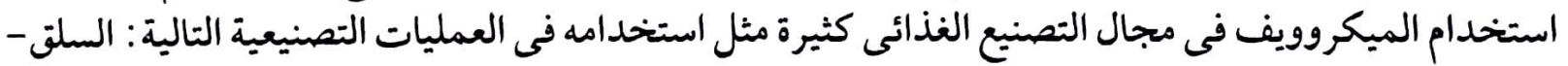

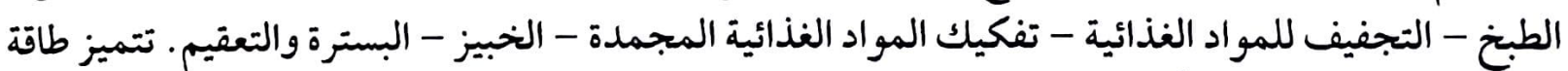

$$
\begin{aligned}
& \text { الميكروويف بعدة صفات أفضل من التسخين بالطرق التقليدية. }
\end{aligned}
$$

